\title{
Performance of Electrical Power Distribution Network Under Dynamic Loading
}

\author{
Ramadoni Syahputra $^{* 1}$, Taufiq Akbar ${ }^{1}$, and Faaris Mujaahid ${ }^{1}$ \\ ${ }^{1}$ Department of Electrical Engineering, Universitas Muhammadiyah Yogyakarta \\ Jl. Lingkar Selatan, Tamantirto, Kasihan, Yogyakarta, Indonesia \\ *Corresponding author, e-mail: ramadoni@ugm.ac.id
}

\begin{abstract}
This paper presents the performance of the electrical power distribution network under dynamic loading. The performance of a distribution system can be seen from the power losses generated by the network. If the power losses are low, then it can be said that network performance is excellent. Another parameter is the distribution network voltage profile. The voltage profile is significant in the distribution network. A very long distribution line will cause a voltage drop at the end of the network. This condition is very undesirable, so efforts must be made to improve the distribution network voltage profile. The method for correcting the voltage profile is by installing capacitors or reconfiguring the network. In this study, an evaluation of the performance of the distribution network at PLN Temanggung was conducted. The results showed that several network points experienced below-standard voltage drops. Therefore it is recommended to install power capacitors or reconfigure the networks.
\end{abstract}

Keywords: Distribution network, performance, power losses, voltage profile

\section{Introduction}

In the current era of globalization, humans have a dependency on electricity [1]. Electricity has become a basic need inherent in everyday life. Almost all equipment that helps or supports daily activities uses electricity; this is evident when the electricity goes out, then all of our activities will be disrupted [2]-[5]. The use of electricity continues to increase over time. This is related to population growth and the economic growth of an area so that the distribution of electrical energy must be guaranteed [6].

Based on Law No. 30 of 2009, it states that stateowned company (in the case of PT PLN) is the chief executor of the electricity supply business. So that the distribution of electrical energy PT PLN demanded reliable because, in the distribution network, voltage and power losses must occur [7].

Voltage drop is the difference between the source voltage and the load or receiver voltage. This voltage drop is the product of the current flowing in the line and the line impedance [8]-[11]. The higher the value of current and impedance, the more significant the voltage drop. So for more extensive networks and load currents, the higher the voltage drop, the greater [12]. During the day, the power usage is relatively small, and the currents are small so that the voltage drops are getting smaller, conversely when at night the use of immense power and the current is getting bigger, so the voltage drop is getting bigger too.

Power losses are the loss of power in the process of electricity from substations to consumers. This power loss is the product of the square of the current with line resistance. The higher the current flowing in a prisoner, the greater the loss of power [13]. The higher the cross-sectional area of a line, the smaller the power losses. During the day, the power usage is relatively small; then, the current flowing is also small so that the power losses are small. Conversely, when at night the load is getting bigger, the current is also higher so that the power losses are also more significant [14]-[18].

An excellent electric power system must have a 
voltage value that does not exceed the tolerance limits and small power losses. Based on SPLN No. 72 of 1987 , the allowable tolerance for voltage drop is $\leq 5 \%$ of the nominal value, and based on the SPLN No. 10-A of 1996; tolerance losses cannot exceed $\leq 10 \%$ of the power delivered [19]. Constant voltage values will optimize the performance of electrical equipment used by consumers and can reduce financial losses that occur during the transmission and distribution process [20]-[22].

These conditions must not be allowed, because voltage drops and power losses are one of the benchmarks of the efficiency of a distribution network system. To reduce the amount of voltage drop and power losses, one of them is by using Load Tap Chargers, Bank Capacitors, and cable replacement in distribution networks [23]-[25].

The objectives of this study are:

1. Knowing the condition of the medium voltage power system distribution network at PT PLN Temanggung.

2. Knowing the voltage profile and power losses in PT PLN Temanggung.

3. Determine efforts to improve the voltage profile and power losses of medium voltage networks by using Load Tap Chargers, Bank Capacitors, and replacing feeder cables in distribution networks.

4. Knowing the voltage profile and power losses in the feeder after a simulation of repairs.

\section{Literature Study}

\section{II.1 General}

The distribution network is part of the electric power system in the form of a conduit that connects the load center substation and the customer. The function of the distribution network is to distribute electrical energy to customers according to the required power and voltage. Based on the voltage level, the distribution network is divided into two, namely the medium voltage distribution network and the low standing distribution network [26].

Medium voltage distribution networks mostly use a 3-phase 4-wire network, 3-phase wire, and one neutral wire with a $20 \mathrm{kV}$ phase inter-stand, while other parts are 2-phase 1-wire network with $11.5 \mathrm{kV}$ voltage. The low voltage distribution network partly uses a 3 phase 4 wire network similar to a medium voltage distribution network to serve 3 phase customers with a phase voltage of $380 \mathrm{~V}$, while others use a 1 phase 3 wire network with a voltage of $220 \mathrm{~V}$ [29]. Between the low-pressure distribution network and the distribution network Medium voltage distribution transformers are installed according to needs, some are using 3-phase transformers, some are using 1-phase to. The medium voltage distribution network is used to connect between substations with distribution transformers or with medium voltage customers. In contrast, the low voltage distribution network is used to connect the distribution transformer with the low-voltage customer. When a low-voltage network and a medium-voltage network use the same pole, the neutral wire used is just one, as a neutral wire with the two systems.

For customers who use a large enough power, for example, industry, hospital, or campus, usually subscribe to 3 phases with a medium voltage of 20 $\mathrm{kV}$. In the interest of reducing the voltage and its distribution, the customer manages his distribution substation. In contrast, customers with relatively small load power use low voltage and are served by a low voltage distribution network that is connected to a distribution transformer [27]. Figure 1 shows the electrical power system.

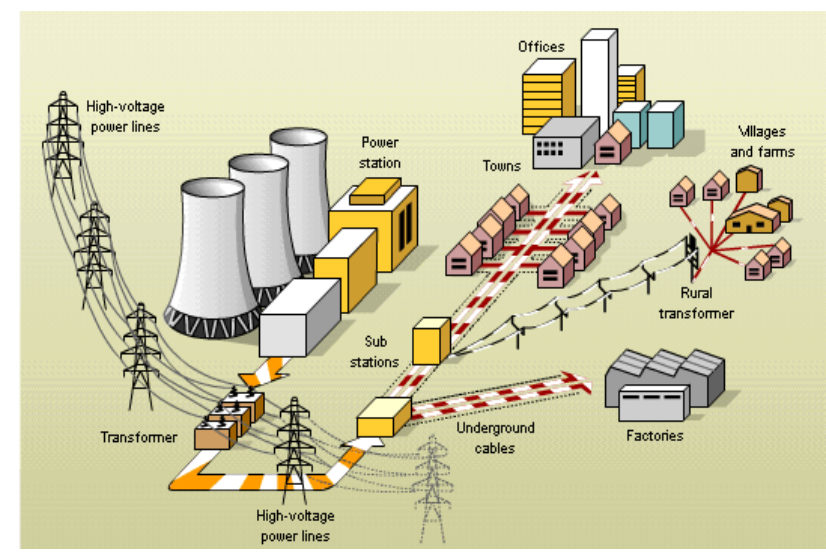

Fig. 1. Electrical power system

Distribution network topologies are grouped into two groups, namely radial networks and loop networks.

\section{II.2 Radial Distribution Network}

The radial distribution network is the simplest network structure, both in terms of planning and effort. The distribution of electric power from feeders is in one direction. As a result, if there is interference at one point in the circuit will cause the entire network will be affected. Thus the continuity of electricity distribution on networks with structures like this is terrible. Because if there is a 
repair at one point will cause the entire network must be extinguished. Figure 2 shows the radial distribution network.

\section{II.3 Loop Distribution Network}

Circle distribution network structure is a closed distribution network structure that starts from considerable resources, then passes through several distribution substations and then returns to the source.

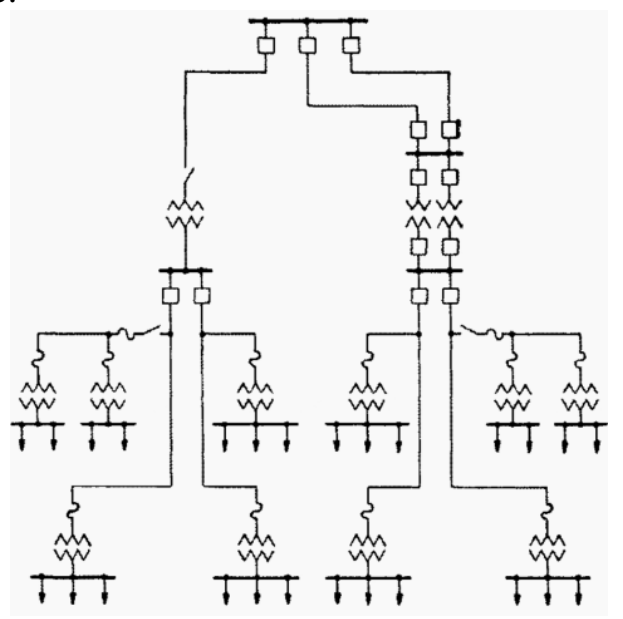

Fig. 2. Radial distribution network
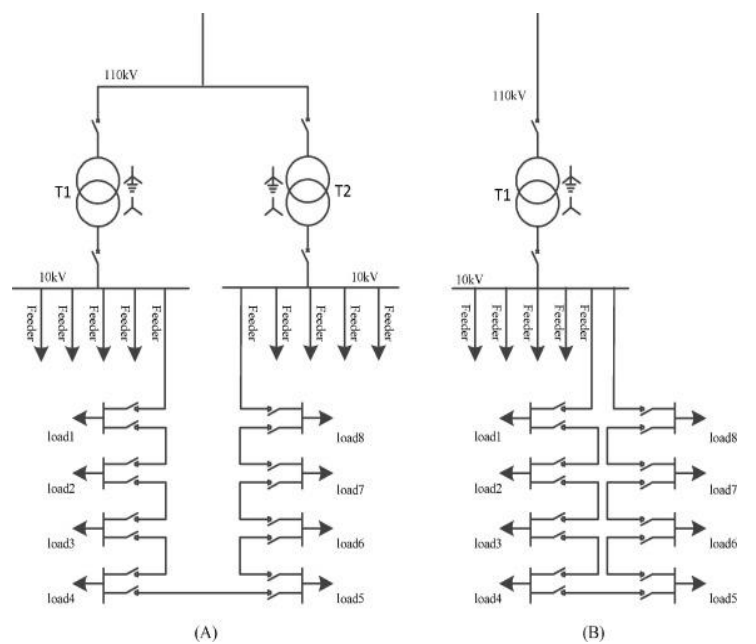

Fig. 3. Loop distribution network

The main advantage of this distribution network structure is that if a disturbance occurs, then the disturbance can be isolated so that it does not interfere with the distribution network as a whole. This can happen because, in this circle distribution network structure, two points can be connected alternately or simultaneously so that the continuity of the distribution is good enough. Even if there is interference at many points in a series or simultaneously, then the entire network can be disturbed as well. Figure 2 shows the radial distribution network, while Figure 3 shows the loop distribution network.

\section{II.4 Electrical Power}

Active power is the power used by actual energy or the power used by consumers; the active power unit is watts. The active power equation can be seen in the following equation [27]:

$$
\mathrm{P}=\mathrm{VI} \cos \emptyset
$$

where,

$$
\begin{aligned}
& \mathrm{P}=\text { Active Power (Watts) } \\
& \mathrm{V}=\text { phase voltage (Volt) } \\
& \mathrm{I}=\text { phase current (Ampere) } \\
& \varnothing=\text { Power factor }
\end{aligned}
$$

Reactive power is the amount of power needed to form a magnetic field. From the formation of a magnetic field, a magnetic field flux is formed, the reactive power unit is VAR. The reactive power equation can be seen in the following equation [27]:

$$
\mathrm{Q}=\mathrm{V} \mathrm{I} \sin \emptyset
$$

where,

$$
\begin{aligned}
& Q=\text { Reactive Power (VAR) } \\
& V=\text { phase voltage (Volt) } \\
& I=\text { phase current (Ampere) } \\
& \varnothing=\text { Power factor }
\end{aligned}
$$

The apparent power is the power generated by the multiplication of RMS voltage and RMS current in a network or power, which is the sum of active trigonometric power and reactive power. The real power unit is VA.

\section{Methodology}

In this study, the tools used are as follows:

1. Hardware

The hardware used by the author is 1 unit of Asus A456QR laptop, 1 unit of the printer and 16 GB flash storage

\section{Software}

The software used is Microsoft Word 2016, Microsoft Exel 2016, and ETAP software.

3. Material for data collection in PT. PLN Temanggung, journals, conferences, and research supporting books.

The authors conducted research and data collection of time and place on May 17, 2018 to June 17, 2018 at PT PLN Rayon Temanggung, located on Jalan Jendral Sudirman, Kowangan, Temanggung, Central Java province, Indonesia. 


\section{Results and Discussion}

\section{IV.1 Network Structure}

TABLE I

DATA OF DISTRIBUTION TRANSFORMER

\begin{tabular}{cccc}
\hline No. & $\begin{array}{c}\text { Transformer } \\
\text { Code }\end{array}$ & $\begin{array}{c}\text { Transformer } \\
\text { Capacity (kVA) }\end{array}$ & Load (kVA) \\
\hline 1 & T2 & 350 & 150 \\
2 & T3 & 550 & 230 \\
3 & T4 & 555 & 264 \\
4 & T5 & 675 & 362 \\
5 & T6 & 750 & 336 \\
6 & T7 & 275 & 79 \\
7 & T8 & 425 & 168 \\
8 & T9 & 475 & 184 \\
9 & T11 & 775 & 317 \\
10 & T12 & 565 & 217 \\
11 & T13 & 625 & 223 \\
12 & T14 & 625 & 279 \\
13 & T15 & 775 & 303 \\
14 & T16 & 500 & 261 \\
15 & T17 & 525 & 246 \\
16 & T18 & 450 & 222 \\
17 & T19 & 750 & 96 \\
18 & T20 & 100 & 90 \\
19 & T21 & 210 & 33 \\
20 & T23 & 825 & 290 \\
21 & T24 & 375 & 65 \\
22 & T25 & 600 & 105 \\
\hline
\end{tabular}

At this stage, the simulation results of the stress profile and power loss program simulation will be explained using the Newton-Rapson flow method. The data collected is based on PLN's report during 2017, while the data on the type of delivery size follows the SPLN standard No. 064 of 1985. After all the data is filled in ETAP 12.6.0, the first simulation is a simulation of the initial state of the SCG 05 feeder and after it is known to have a voltage drop and power losses. There are three methods used in repairing the voltage profile and power losses, namely the first repair using Load Tap Changer, the second repair using a capacitor bank, the third repair using cable replacement. After a simulation of improvement of the three methods will then be compared, which method is most suitable to use.

The SCG 05 feeder is a radial primary $20 \mathrm{kv}$ distribution network supplied from the transformer GI 60 MV substation Secang, Central Java. This feeder has a total load of distribution transformer of 11,730 KVA spread over the SCG 05 feeder network.

The distribution network used in SCG 05 feeders is a 3-phase distribution network where all distribution transformers are used using 3-phase transformers. Distribution network construction consists of a $20 \mathrm{kV}$ Medium Voltage Network. Data of distribution transformer in Temanggung distribution system wa shown in Table I.

\section{IV.2 ETAP Simulation}

From the results of the calculation of power losses using the existing formula with the results of the ETAP 12.6 simulation program, the same results can be obtained; although there is a difference, the difference is minimal. This proves that there is no difference between the existing formula and ETAP 12.6 simulation results, as seen in Figure 4.

To find the total active and reactive power losses in SCG 05 feeders is to add the conductor power losses with the power losses in the distribution transformer.

Furthermore, to improve the performance of the distribution network, cable replacement methods can also be performed. In this method, the repair is done by replacing the distribution network cable with a cross-sectional area of $150 \mathrm{~mm}^{2}$ to $240 \mathrm{~mm}^{2}$, where the value of the impedance of the cable with a cross-sectional area of $240 \mathrm{~mm}^{2}$ has a smaller impedance compared to cables with a crosssectional area of $150 \mathrm{~mm}^{2}$. After changing the cable, the simulation is performed again to see the voltage profile data and power losses in the SCG 05 feeder.

From the comparative data of the difference in voltage profile and power losses between methods it can be concluded that the method of repair that is able to improve the voltage profile and reduce significant power losses is the method of installing bank capacitors, where this method has a profile on bus 40 of $19,352 \mathrm{kV}$ even though at the load tap changer arrangement method has a larger voltage profile, but the voltage profile for the capacitor bank installation method is already within tolerance limits. As well as active power losses of $108.8 \mathrm{~kW}$ and reactive power losses of $191.8 \mathrm{kVar}$, this reduction in power losses are the largest of all methods used.

The total length of SCG 05 feeders in the Temanggung distribution system is $40.5 \mathrm{~km}$ using $240 \mathrm{~mm}$ and $150 \mathrm{~mm}$ XLPE cables. Data on cable length and specifications used in the Temanggung distribution system can be seen in Table II. Furthermore, power losses in the introduction of the Temanggung distribution system during the existing conditions can be seen in Table III, while the 
voltage drop was shown in Table IV. These power simulation software, as shown in Figure 4. losses and voltage drop are obtained using ETAP

TABLE II

Total Conductor Resistance Data Used in the Temanggung System Distribution Network

\begin{tabular}{|c|c|c|c|c|c|c|c|c|}
\hline \multirow{2}{*}{ No. } & \multirow{2}{*}{ from } & \multirow{2}{*}{ to } & \multirow{2}{*}{$\begin{array}{l}\text { Length } \\
(\mathrm{km})\end{array}$} & \multirow{2}{*}{$\begin{array}{c}\text { Cross-sectional } \\
\text { area }\end{array}$} & \multicolumn{2}{|c|}{$\mathrm{Z}(\Omega / \mathrm{km})$} & \multicolumn{2}{|c|}{ Total $(\Omega)$} \\
\hline & & & & & $\mathrm{R}$ & $\mathrm{X}$ & $\mathrm{R}$ & $\mathrm{X}$ \\
\hline 1 & Bus 3 & Bus 4 & 5 & $240 \mathrm{~mm}^{2}$ & 0.125 & 0.097 & 0.625 & 0.485 \\
\hline 2 & Bus 4 & Bus 5 & 1.4 & $240 \mathrm{~mm}^{2}$ & 0.125 & 0.097 & 0.175 & 0.1358 \\
\hline 3 & Bus 5 & Bus 6 & 3.5 & $240 \mathrm{~mm}^{2}$ & 0.125 & 0.097 & 0.438 & 0.3395 \\
\hline 4 & Bus 6 & Bus 7 & 1.5 & $240 \mathrm{~mm}^{2}$ & 0.125 & 0.097 & 0.188 & 0.1455 \\
\hline 5 & Bus 7 & Bus 8 & 2.7 & $150 \mathrm{~mm}^{2}$ & 0.206 & 0.104 & 0.556 & 0.2808 \\
\hline 6 & Bus 8 & Bus 9 & 2 & $150 \mathrm{~mm}^{2}$ & 0.206 & 0.104 & 0.412 & 0.208 \\
\hline 7 & Bus 9 & Bus 38 & 0.8 & $150 \mathrm{~mm}^{2}$ & 0.206 & 0.104 & 0.165 & 0.0832 \\
\hline 8 & Bus 6 & Bus 10 & 2.4 & $240 \mathrm{~mm}^{2}$ & 0.125 & 0.097 & 0.300 & 0.2328 \\
\hline 9 & Bus 10 & Bus 12 & 1.4 & $240 \mathrm{~mm}^{2}$ & 0.125 & 0.097 & 0.175 & 0.1358 \\
\hline 10 & Bus 12 & Bus 13 & 1.7 & $240 \mathrm{~mm}^{2}$ & 0.125 & 0.097 & 0.213 & 0.1649 \\
\hline 11 & Bus 13 & Bus 14 & 4 & $240 \mathrm{~mm}^{2}$ & 0.125 & 0.097 & 0.500 & 0.388 \\
\hline 12 & Bus 13 & Bus 15 & 1.7 & $240 \mathrm{~mm}^{2}$ & 0.125 & 0.097 & 0.213 & 0.1649 \\
\hline 13 & Bus 15 & Bus 16 & 6 & $240 \mathrm{~mm}^{2}$ & 0.125 & 0.097 & 0.750 & 0.582 \\
\hline 14 & Bus 16 & Bus 17 & 3 & $150 \mathrm{~mm}^{2}$ & 0.206 & 0.104 & 0.618 & 0.312 \\
\hline 15 & Bus 16 & Bus 18 & 3.4 & $240 \mathrm{~mm}^{2}$ & 0.125 & 0.097 & 0.425 & 0.3298 \\
\hline 16 & Bus 18 & Bus 19 & 2 & $150 \mathrm{~mm}^{2}$ & 0.206 & 0.104 & 0.412 & 0.208 \\
\hline 17 & Bus 19 & Bus 20 & 4 & $150 \mathrm{~mm}^{2}$ & 0.206 & 0.104 & 0.824 & 0.416 \\
\hline 18 & Bus 20 & Bus 22 & 0.4 & $150 \mathrm{~mm}^{2}$ & 0.206 & 0.104 & 0.082 & 0.0416 \\
\hline 19 & Bus 20 & Bus 21 & 0.7 & $150 \mathrm{~mm}^{2}$ & 0.206 & 0.104 & 0.144 & 0.0728 \\
\hline 20 & Bus 21 & Bus 40 & 1 & $150 \mathrm{~mm}^{2}$ & 0.206 & 0.104 & 0.206 & 0.104 \\
\hline
\end{tabular}

TABLE III

Power Losses of the TemangGung System Distribution Network AT Existing Condition

\begin{tabular}{|c|c|c|c|c|c|c|c|}
\hline \multirow{2}{*}{ No. } & \multirow{2}{*}{ from and to } & \multirow{2}{*}{$\begin{array}{c}\text { Length } \\
(\mathrm{km})\end{array}$} & \multirow{2}{*}{$\begin{array}{c}\text { Electrical } \\
\text { Current } \\
\text { (A) }\end{array}$} & \multicolumn{2}{|c|}{ Measured Losses } & \multicolumn{2}{|c|}{ Calculated Losses } \\
\hline & & & & $\mathrm{kW}$ & $\mathrm{kVar}$ & $\mathrm{kW}$ & kVar \\
\hline 1 & Bus 3 - Bus 4 & 5 & 134.7 & 32.4 & 26.4 & 34.045 & 26.419 \\
\hline 2 & Bus 4 - Bus 5 & 1.4 & 130.3 & 9.1 & 7.4 & 8.915 & 6.918 \\
\hline 3 & Bus 5 - Bus 6 & 3.5 & 123.8 & 19.1 & 15.5 & 20.025 & 15.539 \\
\hline 4 & Bus 6 - Bus 7 & 1.5 & 38.7 & 0.8 & 0.7 & 0.842 & 0.653 \\
\hline 5 & Bus 7 - Bus 8 & 2.7 & 28.1 & 1.3 & 0.7 & 1.319 & 0.666 \\
\hline 6 & Bus 8 - Bus 9 & 2 & 17.3 & 0.4 & 0.2 & 0.370 & 0.187 \\
\hline 7 & Bus 9 - Bus 38 & 0.8 & 7.3 & 0.0 & 0.0 & 0.026 & 0.013 \\
\hline 8 & Bus 6 - Bus 10 & 2.4 & 79.7 & 5.4 & 4.4 & 5.717 & 4.436 \\
\hline 9 & Bus 10 - Bus 12 & 1.4 & 74.7 & 2.8 & 2.3 & 2.930 & 2.273 \\
\hline 10 & Bus 12 - Bus 13 & 1.7 & 68.2 & 2.8 & 2.3 & 2.965 & 2.301 \\
\hline 11 & Bus 13 - Bus 14 & 4 & 10.5 & 0.2 & 0.1 & 0.165 & 0.128 \\
\hline 12 & Bus 13 - Bus 15 & 1.7 & 57.6 & 2.0 & 1.6 & 2.115 & 1.641 \\
\hline 13 & Bus 15 - Bus 16 & 6 & 48.2 & 5.0 & 4.1 & 5.227 & 4.056 \\
\hline 14 & Bus 16 - Bus 17 & 3 & 6.5 & 0.0 & 0.0 & 0.078 & 0.040 \\
\hline 15 & Bus 16 - Bus 18 & 3.4 & 41.7 & 2.1 & 1.7 & 2.217 & 1.720 \\
\hline 16 & Bus 18 - Bus 19 & 2 & 35.1 & 1.4 & 0.8 & 1.523 & 0.769 \\
\hline 17 & Bus 19 - Bus 20 & 4 & 23.6 & 1.3 & 0.7 & 1.377 & 0.695 \\
\hline 18 & Bus 20 - Bus 22 & 0.4 & 9.1 & 0.0 & 0.0 & 0.020 & 0.010 \\
\hline 19 & Bus 20 - Bus 21 & 0.7 & 14.5 & 0.1 & 0.0 & 0.091 & 0.046 \\
\hline 20 & Bus 21- Bus 40 & 1 & 6.7 & 0.0 & 0.0 & 0.028 & 0.014 \\
\hline \multicolumn{4}{|c|}{ Total } & 86.3 & 69 & 89.995 & 68.524 \\
\hline
\end{tabular}


TABLE IV Voltage Drop of the Temanggung System Distribution Network at Existing Condition

\begin{tabular}{|c|c|c|c|c|c|c|c|}
\hline No. & from and to & $\begin{array}{l}\text { Length } \\
\text { (km) }\end{array}$ & $\begin{array}{l}\text { Electrical } \\
\text { Current } \\
\text { (A) }\end{array}$ & $\begin{array}{c}\text { Sending } \\
\text { Voltage } \\
(\mathrm{kV})\end{array}$ & $\begin{array}{c}\text { Receiving } \\
\text { Voltage } \\
(\mathrm{kV})\end{array}$ & $\begin{array}{c}\text { Measured } \\
\text { Voltage } \\
\text { Drop }(\mathrm{kV})\end{array}$ & $\begin{array}{c}\text { Percentage of } \\
\text { Voltage Drop } \\
(\%)\end{array}$ \\
\hline 1 & Bus 3 - Bus 4 & 5 & 134.75 & 19.848 & 19.672 & 0.176 & 0.89 \\
\hline 2 & Bus 4 - Bus 5 & 1.4 & 130.31 & 19.672 & 19.621 & 0.051 & 0.26 \\
\hline 3 & Bus 5 - Bus 6 & 3.5 & 123.52 & 19.621 & 19.508 & 0.113 & 0.58 \\
\hline 4 & Bus 6 - Bus 7 & 1.5 & 38.68 & 19.508 & 19.493 & 0.015 & 0.08 \\
\hline 5 & Bus 7 - Bus 8 & 2.7 & 28.12 & 19.493 & 19.464 & 0.029 & 0.15 \\
\hline 6 & Bus 8 - Bus 9 & 2 & 17.3 & 19.464 & 19.45 & 0.014 & 0.07 \\
\hline 7 & Bus 9 - Bus 38 & 0.8 & 7.3 & 19.45 & 19.448 & 0.002 & 0.01 \\
\hline 8 & Bus 6 - Bus 10 & 2.4 & 79.7 & 19.508 & 19.458 & 0.05 & 0.26 \\
\hline 9 & Bus 10 - Bus 12 & 1.4 & 74.7 & 19.458 & 19.431 & 0.027 & 0.14 \\
\hline 10 & Bus 12 - Bus 13 & 1.7 & 68.2 & 19.431 & 19.4 & 0.031 & 0.16 \\
\hline 11 & Bus 13 - Bus 14 & 4 & 10.5 & 19.4 & 19.389 & 0.011 & 0.06 \\
\hline 12 & Bus 13 - Bus 15 & 1.7 & 57.6 & 19.4 & 19.375 & 0.025 & 0.13 \\
\hline 13 & Bus 15 - Bus 16 & 6 & 48.2 & 19.375 & 19.299 & 0.076 & 0.39 \\
\hline 14 & Bus 16 - Bus 17 & 3 & 6.5 & 19.299 & 19.299 & 0 & 0.00 \\
\hline 15 & Bus 16 - Bus 18 & 3.4 & 41.7 & 19.299 & 19.262 & 0.037 & 0.19 \\
\hline 16 & Bus 18 - Bus 19 & 2 & 35.1 & 19.262 & 19.235 & 0.027 & 0.14 \\
\hline 17 & Bus 19 - Bus 20 & 4 & 23.6 & 19.235 & 19.199 & 0.036 & 0.19 \\
\hline 18 & Bus 20 - Bus 22 & 0.4 & 9.1 & 19.199 & 19.197 & 0.002 & 0.01 \\
\hline 19 & Bus 20 - Bus 21 & 0.7 & 14.5 & 19.199 & 19.195 & 0.004 & 0.02 \\
\hline 20 & Bus 21- Bus 40 & 1 & 6.7 & 19.195 & 19.192 & 0.003 & 0.02 \\
\hline
\end{tabular}

TABLE V

Voltage Drop of the Temanggung System Distribution Network AFTer Conductor RePlacement

\begin{tabular}{cccccccc}
\hline No. & $\begin{array}{c}\text { Identity } \\
\text { of Bus }\end{array}$ & $\begin{array}{c}\text { Voltage } \\
\text { Before } \\
\text { Conductor } \\
\text { Replacement } \\
(\mathrm{kV})\end{array}$ & $\begin{array}{c}\text { Voltage After } \\
\text { Conductor } \\
\text { Replacement } \\
(\mathrm{kV})\end{array}$ & $\begin{array}{c}\text { Percentage of } \\
\text { Voltage } \\
\text { Profile } \\
(\%)\end{array}$ & $\begin{array}{c}\Delta \mathrm{V}) \\
(\mathrm{kV})\end{array}$ & $\begin{array}{c}\Delta \mathrm{V} \text {, } \\
(\mathrm{kV})\end{array}$ & $\begin{array}{c}\text { Percentage of } \\
\text { Drop Voltage } \\
\text { Improvement } \\
(\%)\end{array}$ \\
\hline 1 & Bus 3 & 19.848 & 19.848 & 0 & - & - & - \\
2 & Bus 4 & 19.672 & 19.672 & 0 & 0.176 & 0.176 & 0 \\
3 & Bus 5 & 19.621 & 19.621 & 0 & 0.051 & 0.051 & 0 \\
4 & Bus 6 & 19.508 & 19.508 & 0 & 0.113 & 0.113 & 0 \\
5 & Bus 7 & 19.493 & 19.493 & 0 & 0.015 & 0.015 & 0 \\
6 & Bus 8 & 19.464 & 19.473 & 0.046 & 0.029 & 0.02 & 31.034 \\
7 & Bus 9 & 19.45 & 19.464 & 0.072 & 0.014 & 0.009 & 35.714 \\
8 & Bus 10 & 19.458 & 19.458 & 0 & 0.050 & 0.05 & 0 \\
9 & Bus 12 & 19.431 & 19.431 & 0 & 0.027 & 0.027 & 0 \\
10 & Bus 13 & 19.4 & 19.4 & 0 & 0.031 & 0.031 & 0 \\
11 & Bus 14 & 19.389 & 19.389 & 0 & 0.011 & 0.011 & 0 \\
12 & Bus 15 & 19.375 & 19.375 & 0 & 0.025 & 0.025 & 0 \\
13 & Bus 16 & 19.299 & 19.299 & 0 & 0.076 & 0.076 & 0 \\
14 & Bus 17 & 19.299 & 19.299 & 0 & 0.000 & 0 & 0 \\
15 & Bus 18 & 19.262 & 19.262 & 0 & 0.037 & 0.037 & 0 \\
16 & Bus 19 & 19.235 & 19.244 & 0.047 & 0.027 & 0.018 & 33.333 \\
17 & Bus 20 & 19.199 & 19.219 & 0.104 & 0.036 & 0.025 & 30.556 \\
18 & Bus 21 & 19.195 & 19.217 & 0.115 & 0.004 & 0.002 & 50 \\
19 & Bus 22 & 19.197 & 19.218 & 0.109 & 0.002 & 0.001 & 50 \\
20 & Bus 38 & 19.448 & 19.463 & 0.077 & 0.002 & 0.001 & 50 \\
21 & Bus 40 & 19.192 & 19.215 & 0.120 & 0.003 & 0.002 & 33.333 \\
\hline
\end{tabular}




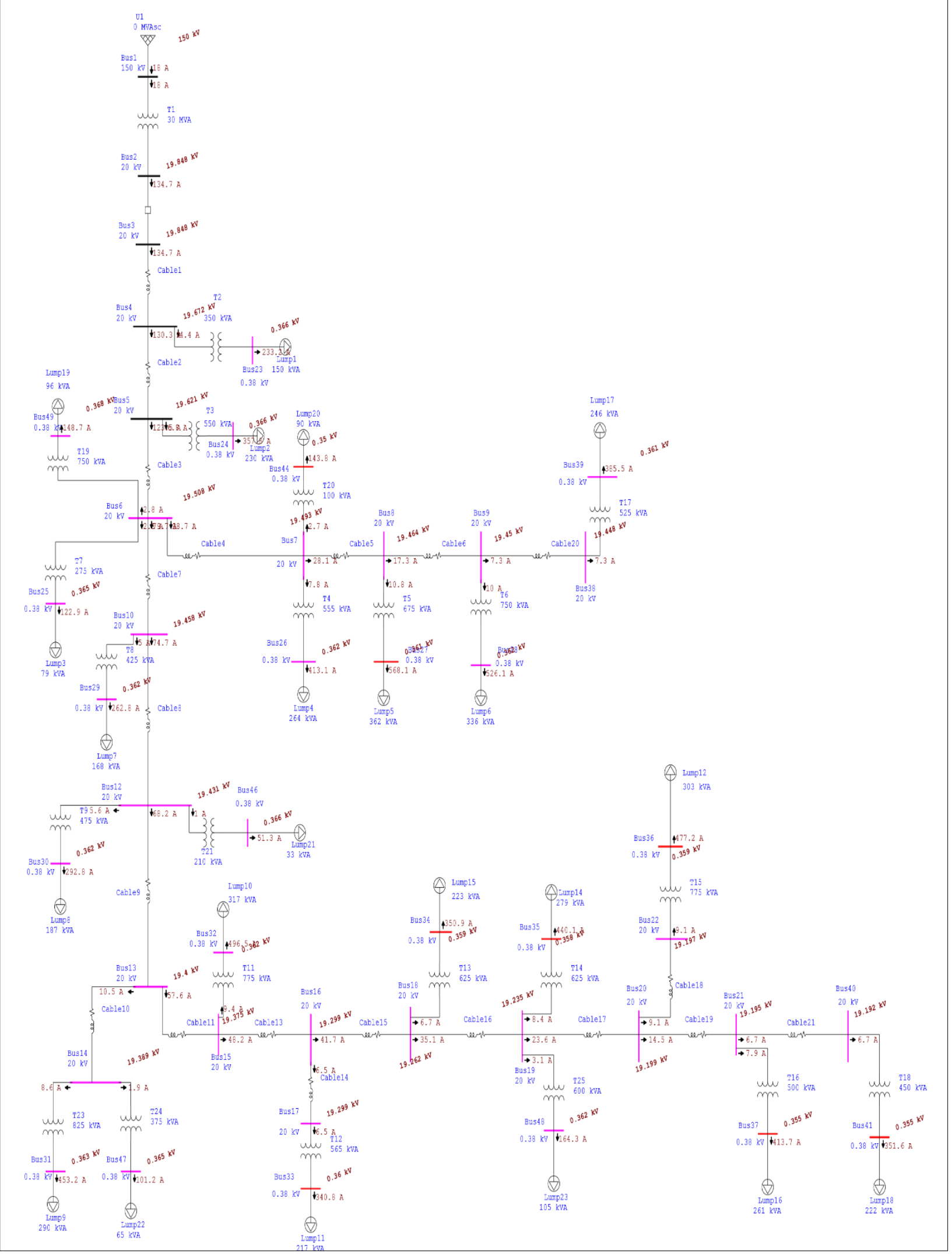

Fig. 4. ETAP simulation results of power losses of the Temanggung distribution system existing conditions 


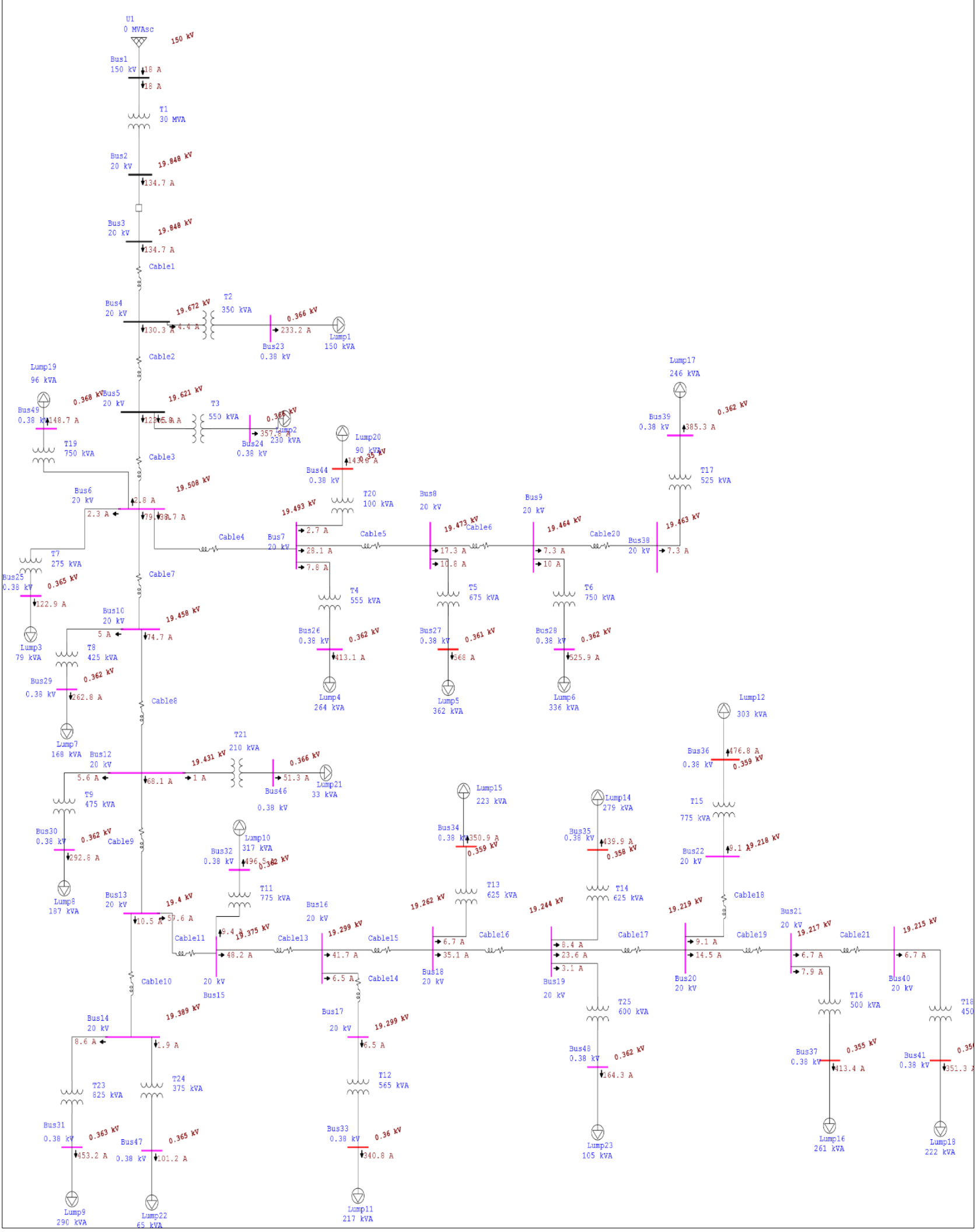

Fig. 5. ETAP simulation results of power losses of the Temanggung distribution system after conductor replacement 
ETAP simulation results of power losses of the Temanggung distribution system after conductor replacement was shown in Figure 5. This simulation produces voltage profile data before and after the replacement of the distribution network conductor. The voltage profile before and after the conductor replacement in the Temanggung distribution system is shown in Table $\mathrm{V}$.

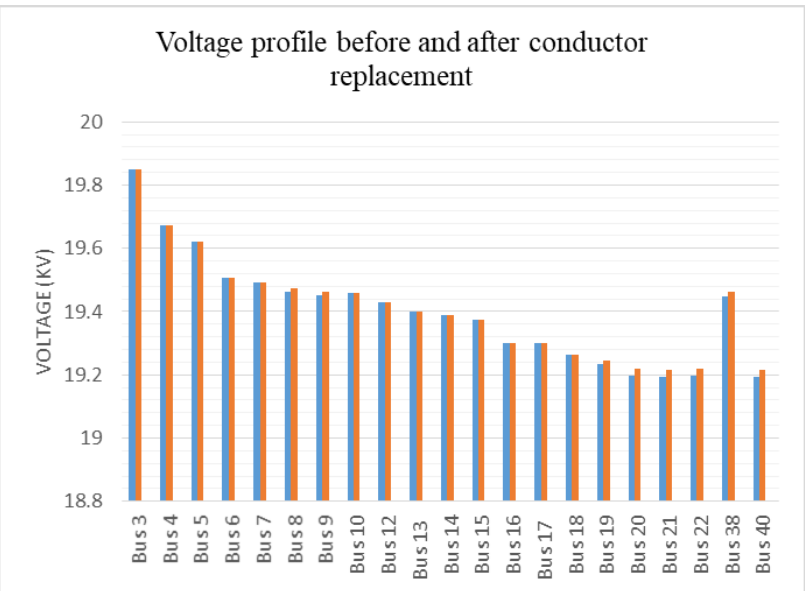

Fig. 6. Voltage profile before and after conductor replacement of Temanggung distribution system

As can be seen in Table V, that after repairs have been made through replacement of the conduit on the distribution network, an increase in the voltage profile on the bus $8,9,19,20,21,22,38$, and bus 40. This increase also improves the network voltage on the buses, where before the conductor replacement experiences a voltage drop.

The condition after the repair scenario is done by replacing the SCG 05 feeder cable, some buses have dropped, and some have not changed. However, this voltage drop is only slightly due to cable replacement only replacing cables that still use a $150 \mathrm{~mm}^{2}$ cross-sectional area. Current flowing in the feeder only slightly decreases wherein the initial condition the current flowing by $134.75 \mathrm{~A}$ decreases to $134.71 \mathrm{~A}$. This decrease causes a decrease in voltage drop not to have a significant effect.

From the improvement scenarios above it can be seen that the increase in pad voltage of bus 8 is $0.046 \%$, bus 9 is $0.072 \%$, bus 19 is $0.047 \%$, bus 20 is $0.104 \%$, bus 21 is $0.115 \%$, bus 22 is $0.109 \%$, bus 38 is $0.077 \%$, and bus 40 by $0.12 \%$ from the existing condition. Because cable replacement is carried out in part, ie, on a cable whose crosssectional area is $150 \mathrm{~mm}^{2}$ to $240 \mathrm{~mm}^{2}$, some buses on the SCG 05 feeder also experience variable voltage profile increases, especially on buses whose cables are replaced. Voltage profile before and after conductor replacement of Temanggung distribution system was shown in Figure 6. In the figure, it can be seen that in general, after cable replacement, the distribution system voltage profile is getting better.

\section{Conclusion}

From the results of simulations and analyses that have been made, the following conclusions can be drawn. In the existing condition, SCG 05 feeders have decreased voltage to the end of the network, namely bus 40 by $19,192 \mathrm{kV}$ and active power losses by $121.3 \mathrm{~kW}$ and reactive power losses by 202.7 kVar. Cross-sectional area replacement is performed on a network that still uses a $150 \mathrm{~mm} 2$ cross-sectional area. After the simulation, the result of the voltage at the end of the network is bus 40 equal to $19,215 \mathrm{kV}$, the bus that experiences a voltage increase is only on the bus whose cable has been replaced only while the bus that has not changed. Active power losses of $119.5 \mathrm{~kW}$ and reactive power losses of $202.5 \mathrm{kVar}$.

\section{References}

[1] Brusco, G., A. Burgio, D. Menniti, A. Pinnarelli, N. Sorrentino. (2014). Optimal Sizing of DGs for a CHP-Based Agro-Industrial Microgrid with a Priority Criteria Operational Strategy, International Review of Electrical Engineering (IREE), 9(2), pp. 351-362.

[2] Syahputra, R., Soesanti, I. (2017). Modeling of Wind Power Plant with Doubly-Fed Induction Generator. Jurnal Teknologi, Journal of Electrical Technology UMY (JET-UMY), 1(3), pp. 126-134.

[3] Syahputra, R., Soesanti, I., Ashari, M. (2016). Performance Enhancement of Distribution Network with DG Integration Using Modified PSO Algorithm. Journal of Electrical Systems (JES), 12(1), pp. 1-19.

[4] Syahputra, R., Robandi, I., Ashari, M. (2015). Performance Improvement of Radial Distribution Network with Distributed Generation Integration Using Extended Particle Swarm Optimization Algorithm. International Review of Electrical Engineering (IREE), 10(2). pp. 293-304.

[5] Mujaahid, F., Fauzi, A.M., Syahputra, R., Putra, K.T., Purwanto, K. (2017). Potentials of Organic Waste Conversion in a Green Campus Concept. Journal of Electrical Technology UMY (JET-UMY), 1(4), pp. 183-188.

[6] Ahmed, J., Salam, Z. (2018). An Enhanced Adaptive P\&O MPPT for Fast and Efficient Tracking Under Varying Env Conditions, IEEE Transactions on Sustainable Energy, 9(3), pp. 1487-1496.

[7] Syahputra, R. (2017). Distribution Network Optimization Based on Genetic Algorithm. Jurnal 
Teknologi, Journal of Electrical Technology UMY (JET-UMY), 1(1), pp. 1-9.

[8] Hui, J.C.y., Bakhshai, A., Jain, P.K. (2016). An Energy Management Scheme With Power Limit Capability and an Adaptive Maximum Power Point Tracking for Small Standalone PMSG Wind Energy Systems, IEEE Transactions on Power Electronics, 31(7), pp. 4861 - 4875.

[9] Hui, J.C.y., Bakhshai, A., Jain, P.K. (2015). A Sensorless Adaptive Maximum Power Point Extraction Method With Voltage Feedback Control for Small Wind Turbines in Off-Grid Applications, IEEE Journal of Emerging and Selected Topics in Power Electronics, 3(3), pp. 817 - 828.

[10] Syahputra, R., Robandi, I., Ashari, M. (2014). Optimization of Distribution Network Configuration with Integration of Distributed Energy Resources Using Extended Fuzzy Multi-objective Method. International Review of Electrical Engineering (IREE), 9(3), pp. 629-639.

[11] Jiang, R., Han, Y., Zhang, S. (2017). Wide-range, high-precision and low-complexity MPPT circuit based on perturb and observe algorithm, Electronics Letters, 53(16), pp. 1141 - 1142.

[12] Peng, B.R., Che, K., Liu, Y.H. (2018). A Novel and Fast MPPT Method Suitable for Both Fast Changing and Partially Shaded Conditions, IEEE Transactions on Industrial Electronics, 65(4), pp. 3240 - 3251.

[13] Hossain, M.K., Ali, M.H. (2013). Overview on Maximum Power Point Tracking (MPPT) Techniques for Photovoltaic Power Systems. International Review of Electrical Engineering (IREE), 8(4). pp. 1363-1378.

[14] Tang, L., Xu, W., Mu, C. (2017). Analysis for stepsize optimisation on MPPT algorithm for photovoltaic systems, IET Power Electronics, 10(13), pp. 1647 - 1654.

[15] Ghasemi, M.A., Ramyar, A., Eini, H.I. (2018). MPPT Method for PV Systems Under Partially Shaded Conditions by Approximating I-V Curve, IEEE Transactions on Industrial Electronics, 65(5), pp. 3966 - 3975.

[16] Soesanti, I., Syahputra, R. (2016). Batik Production Process Optimization Using Particle Swarm Optimization Method. Journal of Theoretical and Applied Information Technology (JATIT), 86(2), pp. 272-278.

[17] Syahputra, R., Robandi, I., Ashari, M. (2015). PSO Based Multi-objective Optimization for Reconfiguration of Radial Distribution Network. International Journal of Applied Engineering Research (IJAER), 10(6), pp. 14573-14586.

[18] Metry, M., Shadmand, M.B., Balog, R.S., Abu-Rub, H. (2017). MPPT of Photovoltaic Systems Using Sensorless Current-Based Model Predictive Control, IEEE Transactions on Industry Applications, 53(2), pp. 1157 - 1167.

[19] Soedibyo, Ashari, M., Syahputra, R. (2014). "Power loss reduction strategy of distribution network with distributed generator integration", Proceeding of 2014 1st International Conference on Information Technology, Computer, and Electrical Engineering (ICITACEE) 2014, UNDIP Semarang, pp. 404 408.

[20] Kebede, M.H., Beyene, G.B. (2018). Feasibility Study of PV-Wind-Fuel Cell Hybrid Power System for Electrification of a Rural Village in Ethiopia. Journal of Electrical and Computer Engineering, 2018.

[21] Jamal, A., Suripto, S., Syahputra, R. (2015). MultiBand Power System Stabilizer Model for Power Flow Optimization in Order to Improve Power System Stability. Journal of Theoretical and Applied Information Technology (JATIT), 80(1), pp. 116123.

[22] Syahputra, R., Soesanti, I. (2015). Power System Stabilizer model based on Fuzzy-PSO for improving power system stability. 2015 International Conference on Advanced Mechatronics, Intelligent Manufacture, and Industrial Automation (ICAMIMIA), Surabaya, 15-17 Oct. 2015 pp. 121 126.

[23] Syahputra, R., Soesanti, I. (2016). Application of Green Energy for Batik Production Process. Journal of Theoretical and Applied Information Technology (JATIT), 91(2), pp. 249-256.

[24] L. Tang, W. Xu, C. Mu, "Analysis for step-size optimisation on MPPT algorithm for photovoltaic systems", IET Power Electronics, Vol. 10, No. 13, pp. 1647 - 1654, 2017.

[25] Sher, H.A., Addoweesh, K.E., Al-Haddad, K. (2018). An Efficient and Cost-Effective Hybrid MPPT Method for a Photovoltaic Flyback Microinverter, IEEE Transactions on Sustainable Energy, 9(3), pp. 1137 - 1144.

[26] Syahputra, R., Soesanti, I. (2016). An Optimal Tuning of PSS Using AIS Algorithm for Damping Oscillation of Multi-machine Power System. Journal of Theoretical and Applied Information Technology (JATIT), 94(2), pp. 312-326.

[27] H. Saadat, (1999). Power System Analysis, Singapore, McGraw-Hill, 1999.

\section{Authors' information}

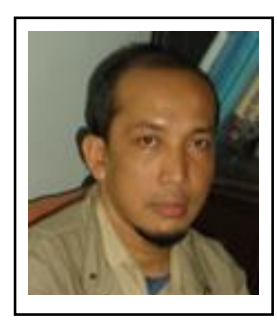

Ramadoni Syahputra received B.Sc. degree from Institut Teknologi Medan in 1998, M.Eng. degree from Department of Electrical Engineering, Universitas Gadjah Mada, Yogyakarta, Indonesia in 2002, and Ph.D degree at the Department of Electrical Engineering, Faculty of Industrial Technology, Institut Teknologi Sepuluh Nopember, Surabaya, Indonesia in 2015.

Dr. Ramadoni Syahputra is a Lecturer in Department of Electrical Engineering, Faculty of Engineering, Universitas Muhammadiyah Yogyakarta, Indonesia. His research interests are in computational of power system, artificial intelligence in power system, power system control, the application of fuzzy 
logic in power system, optimization, distributed energy resources, and renewable energy.

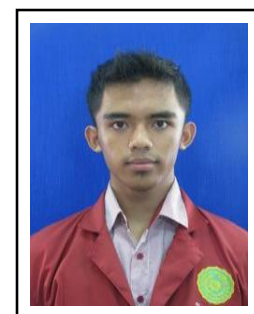

Taufiq Akbar received B.Sc. degree from Department of Electrical Engineering, Universitas Muhammadiyah Muhammadiyah Yogyakarta, Yogyakarta, Indonesia in 2019. His research interests are in operation of power system and power system planning.

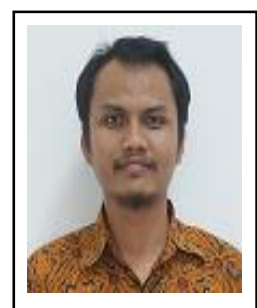

Faaris Mujaahid hold a bachelor degree in 2010 from Electrical and Electronics Engineering Department, Saxion University of Applied Sciences, the Netherlands. He received a master degree in Sustainable Energy Technologies in 2016 from University of Southampton, UK. ing. Faaris Mujaahid, M.Sc is currently a lecturer in the Department of Electrical Engineering, Faculty of Engineering, Universitas Muhammadiyah Yogyakarta, Indonesia. His main research interest is in LabVIEW and renewable energy (mainly in solar cell material and fabrication technologies). 